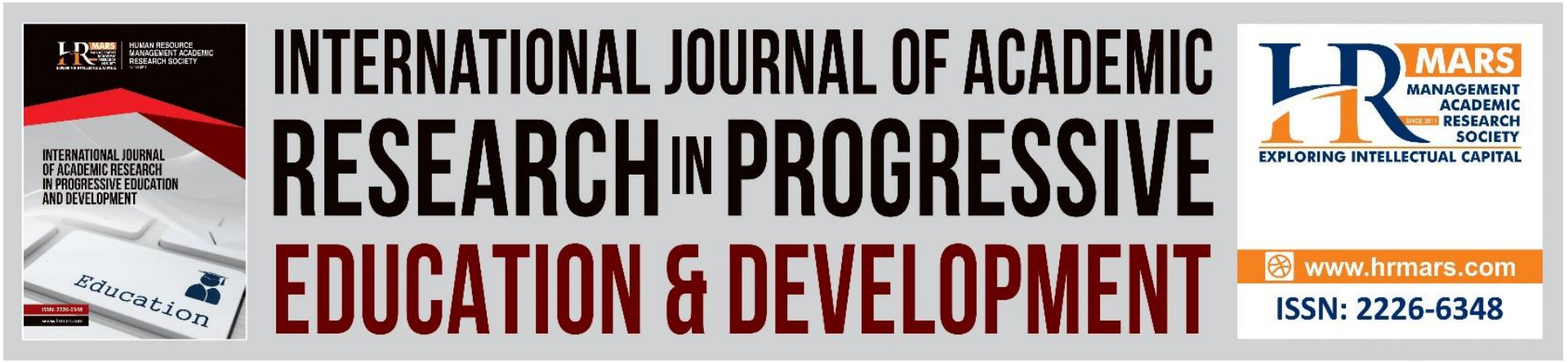

\title{
Violence Against Women in Afganistan: A Case of Nangarhar
}

\section{Imran Zafarzai, Ahmad Shakib Zalmai}

To Link this Article: http://dx.doi.org/10.6007/IJARPED/v10-i2/10673

DOI:10.6007/IJARPED/v10-i2/10673

Received: 04 May 2021, Revised: 26 May 2021, Accepted: 15 June 2021

Published Online: 20 July 2021

In-Text Citation: (Zafarzai \& Zalmai, 2021)

To Cite this Article: Zafarzai, I., \& Zalmai, A. S. (2021). Violence Against Women in Afganistan: A Case of Nangarhar. International Journal of Academic Research in Progressive Education and Development, 10(2), 1096-1103.

Copyright: (c) 2021 The Author(s)

Published by Human Resource Management Academic Research Society (www.hrmars.com)

This article is published under the Creative Commons Attribution (CC BY 4.0) license. Anyone may reproduce, distribute, translate and create derivative works of this article (for both commercial and non-commercial purposes), subject to full attribution to the original publication and authors. The full terms of this license may be seen at: $\underline{\text { http://creativecommons.org/licences/by/4.0/legalcode }}$

Vol. 10(2) 2021, Pg. 1096 - 1103

Full Terms \& Conditions of access and use can be found at http://hrmars.com/index.php/pages/detail/publication-ethics 


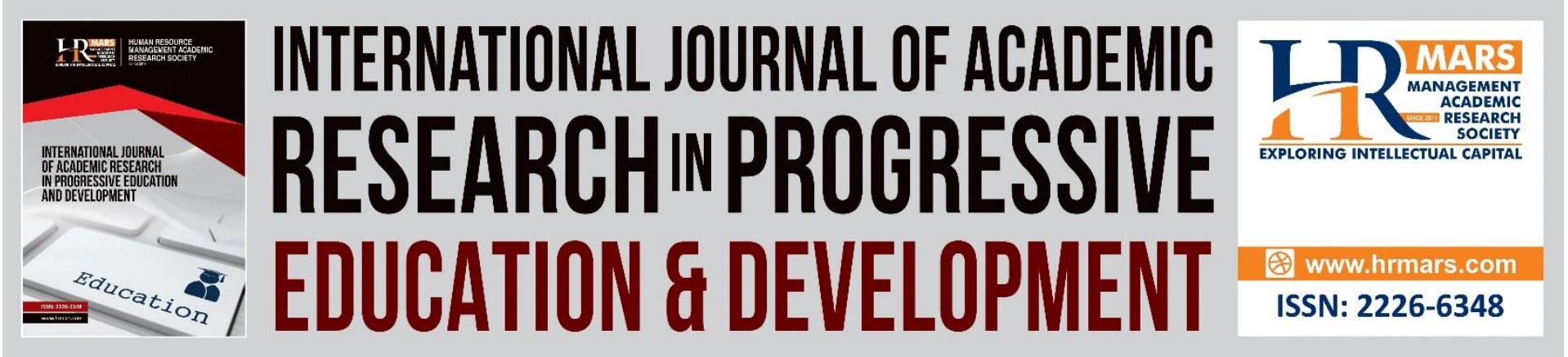

\title{
Violence Against Women in Afganistan: A Case of Nangarhar
}

\author{
Imran Zafarzai \\ Associate Professor Forensic Medicine Department, Medical faculty Nangarhar University, \\ Afghanistan \\ Email: Imranzafarzai22@gmail.com
}

\begin{abstract}
Ahmad Shakib Zalmai
Assistant Professor Forensic Medicine Department, Medical faculty Nangarhar University, Afghanistan

Email: shakibzalmai66@gmail.com
\end{abstract}

\begin{abstract}
This study investigates violence against women in Nangarhar, Afghanistan. It is general consideration that women are more vulnerable towards violence in patriarchal society. The fundamental aim of present study is to find out the major obstacles that women face and creating awareness about various types of violence. To analyze violence, a frame work was developed. Data was collected through interviews from 900 women from urban and rural areas of four districts of Nangarhar Province: Jalalabad, Behsood, Batikot, and Shinwari in the year 2019. Various aspects of Life were interviewed through a well-structured questionnaire, especially the demographics, ways of violence, level of violence and factors which are related to violence. This study provides concise description of the overall scenario of violence against women (VAW) in Nangarhar, Afghanistan. This study is helpful for the policy makers in a way that they understand the nature and severity of violence against women and make
\end{abstract}

Keywords: Violence, Women, Afghanistan

\section{Introduction}

Violence against women (VAW) is commonly used term which means "sex based viciousness that outcomes in physical, mental and rape making enduring ladies, including pressure and danger of such acts, intimidation or subjective deprivation of freedom, regardless of whether happening in private life or in public (Unite Nation, 1993). It is an inescapable infringement of common human liberties (UN Women, 2011). It affects females that belong to any religion, class, age or sexuality (Green, 2004). According to the statistical facts more than $70 \%$ of the women in the world face violence (physical or sexual) in their entire life (UN Women, 2011). Every third women in intimate relation, encounter violence at various occasions of life (Ali, 2008). Based on the aforementioned data, violence is observed as a worldwide problem of women. Women around the globe face different kind of violence including political, cultural, 
social and economic (Ullah, 2020). According to recent data, in every 15-20 seconds a women encounter violence.

From historical prospective, there is a widespread violence against women around the globe. While at the same time women are socially and officially prepared to bear the violence to a higher degree. Such endurance by women and their lower social, economic and legal status make such violent practices easier. Such gender base violence is spread worldwide irrespective of age, religion, race, marital status and class resulting in many health and other societal problems (Buitrago Cuéllar, 2007). Such violence includes acid attacks, forced child abortion, honor killing, sexual harassment, forced prostitution, child marriages, rape (Aurat Foundation, 2012). While there are very large number and cases of violence against women, however the current research focus specifically on violence against women in subcontinent and specifically in Afghanistan (Caritas, 2009).

VAW is a global incident that is not restricted to a particular age, caste, religion, gender, or geographical location. Violence against women mainly aimed at silencing and controlling women. Physical harassment is used as a weapon against women who refuse sexual or other advances that began to rise in many developing nations, specifically in South Asia. The first case of violence occurred in India in 1982. Since then, researchers have witnessed an increase in the amount and severity of acid attacks in the region. In many countries acid attacks constitute a hidden form of violence against women and children that often go unreported and the true number of horrific attacks taking place does not come to light (Saraceno et al., 2007).

Afghanistan is a developing country, have low per capita income. Afghanistan is an agriculture-based country with a population of 32 million (Yusufzada, Xia, \& Xia, 2019). Its borders are shared with China, Tajikistan, Turkmenistan, Iran, and Pakistan. The central administrative governance system is the system of the country (Blunt, Mamundzay, Yama, \& Afghan, 2015). In Afghanistan, VAW has become relatively common practice. In the past years many steps have been taken to highlight the significance of women in the field of education and health, however still several issues exist in the country. Main reason of such an increase in violence in Afghanistan is, that there is no specified policy or rule to handle this sensitive issue (Buitrago Cuéllar, 2017).

According to country statistics $51 \%$ of the women in Afghanistan face life time violence (physical or sexual) by their intimate partners. $46 \%$ of the total women in Afghanistan faced violence (physical or sexual) in last 12 months and much other face violence from nonpartners as well. While forced marriage is also the fate of $35 \%$ of the women in Afghanistan. $90 \%$ women of the country face violence in one form or other. According to statistical report issued by human right organization (2019), in year 2019 around 6500 incidents of VAW are reported while many other still are unreported. Different policies have been proposed and are part of action plan of the government form 2016 in Afghanistan to eradicate violence but unfortunately implementation on these polices is far behind the requirement. Such weak implementations of laws are actually responsible for increase in VAW (UN Women, 2011). Number of cases of violence are still being reported in 2018 before the formulation of policies. Different forms of violence women usually face, include sexual abuse, physical abuse, harassment, rape, forced marriages, acid attacks, forced prostitution, beating, childhood marriages, burning, and exchange of females to settle family disputes (Babur, 2007; Ullah, 2020). 
According to Afghanistan Human Right Commission (AHRC, 2015), forcing women to death and then saying that it was a suicide attempt by her is the worst form of violence. Such events occur either due to dowry disputes (women doesn't bring dowry as expected by the man's family) or in case when men wants to marry another girl. Eligibility of husband to get inheritance in case of death of women is another reason due to which such instances occur. In the recent years some forms of violence increased significantly including acid victimization, sexual assault, honor killing and domestic abuse. Freedom of speech and thought from mistreatment and hunger, equality, equity, justice, accountability transparency and honesty are the necessities of good governance (Miller, 2006).

Nangarhar is an essential focal point of Afghanistan due to many reasons, including its economic potential. Its security challenges. In Nangarhar, there is limited access to necessities of life, including electricity and others. Its economy is based on agriculture and people here have limited access to education (Hashimi, 2016). However, it is a breadwinning province of Afghanistan as it shares the route with Pakistan and provides economic opportunities. It is clear from the above discussion that the political and security situation of Nangarhar was never stable.

According to the Afghanistan Independent Human Rights Commission (2017), cases of such violence become more prominent and increase in number in Nangarhar. Provisional head accepted that in 2015 number of violence cases reported are more as compared to the past years (Miller \& Kushner, 2016). Further it is argued that cultural limitations are main cause. Females in the remote areas of Nangarhar can't share their problems with the concerned authorities.

In the year 2017, women affair director of the Nangarhar reported that from March to September, more than 72 cases of violence have been reported. According to the provincial governor most of the cases were an outcome of domestic violence including divorce, harassment. In 2017 special gatherings was arranged for the support of women. Threat exist for the wellbeing, safety and security of young ladies and women in the working environment in public and inside the families, as borne out by the NGO's, media report and some other organizations.

Throughout the entire existence of human beings, religion has assumed an active function in forming the entire developments. Islam has likewise laid an extraordinary accentuation on the correct liberation of women's rights and has endorsed regard for ladies. To impart any change in society it is very important to unite together for the cause. In same manner to eradicate the curse VAW society as whole should unite for eradication of this barbaric practice. Moreover, women are actually the important and vital part of society and are also responsible for the nourishment of and upraising of our children. Keeping the above fact in mind, it is very important to equip them with their due rights and make them strong enough to face the challenges of society. In this way, there will be a nation that can confront every situation boldly and can come up with urgent workable solutions.

\section{Violence against Women (VAW)}

An Appraisal of the Indian Legal Response (2011) by Nehaluddin Ahmad, the author in the article highlights the evil practice of violence against women. The intentional throwing or pouring of acid with a motive of defacing or killing a person is used as a brutal way of taking revenge. The authors highlighted that the physical as well as psychological consequences of 
such attacks, the authors also cover the insufficiency of the law to give justice to the victims and the possible steps that can be taken to strengthen the law to deal with such attacks.

Vitriolage \& India- the Modern Weapon of Revenge (2013) by Parvathi Menon and Sanjay Vashistha, the author in the article highlights that the common reasons of violence and the post attack evil consequences that the victims and their families undergo. Two of the most important issues raised by the authors in this article are 'role of police in the investigation of violent attacks and judiciary's role in prosecuting the perpetrators of such violent attacks.

From all above discussion, it is crystal clear that VAW have been explained in various ways. In Afghanistan, no study clarified the elements of VAW with rational statistics. This study is an attempt to clarify all the intrinsic and extrinsic factors that significantly affect VAW. In short, this study provide potential answers for issue regarding VAW both at micro and macro level.

\section{Objectives}

The major objectives of this research are broken down into followings;

- To recognize the hindrances faced by females in a man-centric culture.

- To enhance the public awareness of different forms of violence and its consequences

- To find the ways to eliminate violence against women.

- To find out the reasons and impacts of violence against women and techniques to prevent it.

\section{Methodology}

For accomplishment of aforementioned significant objectives of this study, primary data was obtained through a questionnaire. Questionnaire used for the house hold survey was well structured. Sample of total 900 women were taken from which 450 belongs to urban area while 450 were from rural areas. Data was gathered in year 2019 to attain the research objective. Four districts of Nangarhar including Jalalabad, Behsood, Batikot and shinwari were the target area of the survey. A well formulated questionnaire containing different parts (demographic data, ways of violence, level of severity of violence, reason of violence and other related factors) was used to collect data. For analysis of collected data, SPSS has been used. Proportion and percentage test was key to draw the results. With the resultant facts and figures, this study explains the view of VAW in Nangarhar, Afghanistan.

\section{Results and Discusion}

Women are violated in a number of ways, many factors including extrinsic and intrinsic are accountable and effect frequencies of these types. All these types and factors explained below one by one.

\section{Intrinsic Factors}

Individual and biological factors that influence a person's behavior. This incorporate individual attributes of any person e.g. age, training, and acknowledgement of cultural violence practices. Childhood abuse, witnessing abuse of married couples and substance abuse are some of the intrinsic factors that affect VAW in Nangarhar, Afghanistan.

\section{Age vs. Domestic Violence}

The outcomes of previous studies indicate that young girls are more prone to domestic violence but findings of different cross-sectional studies documented that relation between 
violence and age of women is not confirmed. The findings of present study indicate that age of the female and violence is not connected or depended. No age group- can be considered safe because female of every age face violence, only form of violence change with age like married one will be abused mostly by their partners, young girl by their father or brother in the form of forced marriages or by lover in the form of acid attacks. So, every woman of any age face violence but in different forms.

\section{Education vs. Violence}

From the study it is clear that education is directly related with the VAW. Chances of bearing violence are far less in women who have got higher education as compared to the women who do not own any formal education. This difference is because education makes them aware of their basic rights. According to results, in Nangarhar almost $13.2 \%$ of the total women are not aware of their rights and laws. Some of them are urban while the others are rural. In all four districts of Nangarhar which were included in the study have significant number of females who still are unaware of their basic rights and laws that are present for the protection of women in constitution.

It is written in the constitution of the Afghanistan that all human beings are equal and have their own right. Dignity of both male and female are equally important. Discrimination on the basis of sex is not allowed and to include women in different spheres of life we should unite and take some necessary steps. Different articles and rules have been designed for the purpose but lack of education in females makes them to suffer from increased violence as compared the educated females.

\section{Extrrinsic Factors}

There are number of extrinsic theories that explain violence in a detailed manner. These theories clearly explain the reasons of violence including cultural, economic, social and political reasons. Some of the cultural values and constraints are actually the reason due to which violence ratio increase in society. There are number of ways through which females are victimized in their whole life by child marriages in early age, than through forced marriages, acid attacks, murder and exchange of women to settle family disputes, abuse from the partner and threats of divorce and separation.

This study revealed that childhood marriages are highest in Afghanistan. Overall 30\% women reported this kind of violence, $42 \%$ of which belong to rural while the $34 \%$ belong to urban areas. The further breakdown of the total women of Jalalabad reported 55\%, Behsood $44 \%$, Batikot $13 \%$ and Shinwari $18 \%$. From the present data it is clear that childhood marriage is most common and prevailed form of violence.

Bartering of females to settle family disputes is another prevalent form of violence. According to the results, $6 \%$ of total women in Nangarhar reported such kind of violence acts while in Jalalabad, Behsood, Batikot, and Shinwari; $8 \%, 4 \%, 5 \%$ and $10 \%$ women respectively indulge in VAW.

Emotional and psychological abuse is another form of violence faced by many women. Such abuse in most of the cases is done by husband (moderate to low) or by family. Even the females that apparently live a happy life also reported such abuse. Over all $8 \%$ of the women of Nangarhar reported such kind of violence while coming to district level $12 \%$ females of Jalalabad reported the incident while Behsood, Batikot and shinwari reported $14 \%, 5 \%, 1 \%$ cases respectively. 
Controlling women by money is a very famous form of violence. Male try to keep their females uneducated so that they can't earn own and then deny disbursing them money in order to dominate them. $6 \%$ of total Nangarhar women reported such violence (Ullah, 2020). Blackmailing by children and home, $64 \%$ of the total women of Nangarhar reported such incidents. Divorce threatening, $4 \%$ women of Nangarhar reported such kind of violence.

Sex of child, in male dominant society birth of a baby boy is considered a good while that of a girl is considered a bad happening .many females face violence just because they are giving birth to more daughters. Some of them have to face more violence and trouble by their families and partners. But results of the present study indicate that only $5 \%$ women of the Nangarhar faced such kind of violence by their husbands. Overall $6 \%$ of the women of Nangarhar reported that their husband and families were unhappy upon the birth of baby girl. In most of the cases rural families reported more problems while the urban face lower level of violence.

$7 \%$ of total women reported that they were facing violence in past because of so called Jirga systems. From the results of this study, it is clear that the arbitration body in Nangarhar is mainly jirgas (49\%), courts( $28 \%$ ), and police stations (17\%). Study also indicated that women are reluctant to approach formal institution for justice many females only report such incidents to their families while some other were of the opinion that such happenings should not be reported.

Unemployment is a factor reported repeatedly as the cause of such domestic violence against women. Unemployment sometime is the cause while sometime it becomes the reason to increase VAW. Due to this aggression, depression risk increase which in turn results in violent behavior of men towards women.

\section{Conclusion}

This study highlights the different forms and reasons of VAW in Nangarhar, Afghanistan. According to the present study, VAW is highly neglected and vague term. While it is very common in all the districts but comparatively less attention is paid to it. Results show that psychological violence is more prevent as compared to physical one. Women of all ages are prone to violence. Different factors of violence are also very clear from the findings. Women are treated as slaves, forced to early marriages, offered to settle disputes, and are thrown in fire on small family issues. Bartering is also common practice and acid attacks are enough to ruin their whole lives. In addition to physical psychological violence is also common and discussed. Some common reported ways of psychological violence include yelling, marital rape, useless criticism, control by money and threatening to divorce. But still females are not so empowered that they can go and approach some formal system of justice for the purpose.

\section{Policy Implications}

Results of the study will help policy makers understand various types of physical and psychological violence and the factors affecting it. It will also help them to alter the laws so that quality of life of women can be upgraded. A few recommendations are given below;

- To take preventive steps that some changes in curriculum must be done.

- Awareness campaigns regarding women rights should be introduced.

- Sensitization of media can also play important role in prevention of VAW. 
- Such community mobilization programs should be introduced by the government that can enhance awareness of women rights.

- Steps should be taken to implement rules and laws that can eliminate VAW.

- Such measures or practices should be introduced in police and judiciary that women feel secure and protected while facing them.

\section{References}

Ali, P. A., and Gavino, M. I. B. (2008). Violence against Women in Pakistan: A framework for analysis. University of Sheffield UK.

Babur, Z. U. (2007). Violence against Women in Pakistan: Current realities and Strategies for change. European university center.

Bhatti, N., Jamali, M. B., Phulpoto, H. N., Mehmood, T., and Shaikh, F. M. (2011). Domestic Violence against Women: A case study of district Jacobabad, Sindh Pakistan. Asian Social Science, 7(12), 345-365.

Greenan, A. L. (2004). Violence against Women. National group to address the violence against women. Scottish Executive 5(12).

Irfan, H. (2009). Honour related Violence against Women in Pakistan. American Bar Foundation 5(3), 125-131.

Khan, S., and Sajid, M. R. (2011). Violence against Women in Pakistan: A case study of Wife Battering in Rural Gujrat, Pakistan. World Applied Science Journal 12(11), 2168-2174.

Niazi, M. U. (2012). Say "no" to Violence against Women". Frontier Post.

Rennison, C. (2003). Intimate Partner Violence. Bureau of Justice Statistics, Department of Justice, Washington DC.

South Asia Conference. (2011). Reclaiming Space from Victimhood to Agency: State and Civil Society Response to Violence against Women. Elementary education online, 10(4), 145156.

Social Policy and Development Center. (2012). Socio-economic Cost of Violence against Women. Humanities and social sciences reviews 8(12), 342-351.

Ullah, M. (2020). Women Empowerment and Social Development in Afghanistan through Micro Finance. International Journal of Academic Research in Business and Social Sciences, 10 (12), 377-389.

United Nations. (2006). Women and Violence. United Nations Department of Public Information.

UNDP. (2010). Gender Justice and Protection. United Nation Development Program. 